\title{
Determinants of Sustainable Performance and Convergence with EU Agenda 2030: The Case of Romanian Forest Enterprises
}

\author{
Marian Socoliuc $^{1}$, Veronica Grosu, Cristina Gabriela Cosmulese ${ }^{2 *}$, Rozalia Kicsi ${ }^{2}$ \\ ${ }^{1}$ Department of Accounting, Audit and Finance, Stefan cel Mare University, Suceava, Romania \\ ${ }^{2}$ Department of Management, Business Administration and Tourism, Stefan cel Mare University, Suceava, Romania
}

Received: 22 May 2019

Accepted: 16 July 2019

\begin{abstract}
The aim of this paper is focused on analyzing the financial performance indicators of enterprises operating in the fields of forestry and forestry exploitation in northeastern Romania, and their effects on sustainable development in view of the priorities established in the EU, with the adoption by the Member States of the Agenda 2030. In this respect, the most important 200 enterprises in northeastern Romania were selected, and the main performance indicators registered during 2009-2017 were analyzed, and a statistical model in which the balance indicators are correlated with the financial ratios being developed in the sense of assessing the financial or commercial sustainability of enterprises with which to assess the qualitative parameters of sustainable development. Results show that the entities that operate in the field of forestry exploitation, which have an over-average turnover, are more concerned with the acceleration of the rotational speed of the circulating assets with direct favorable effects on performance indicators (benefit and rate of return), but with negative effects on the decrease of the forest fund through its administration policies, which may conflict with article No. 14 of the 2030 Agenda. This paper has an innovative character, assessing the pillar of business activities within sustainable development in objective terms of sustainability.
\end{abstract}

Keywords: sustainability, financial performance, economic determinants, forest enterprises, EU Agenda 2030

\section{Introduction}

The global economic development that has occurred in recent years was made by ignoring the effects it had on the environmental components (forest, water, air), producing deep and sharp changes in their structures.

*e-mail: gabriela.cosmulese@usm.ro
Nowadays, the objective of each business entity, including forest enterprises, is to achieve profits and, at the same time, ensure the sustainability of these entities' activities and social responsibility policy. On the contrary, massive irrational deforestation will inevitably lead to the destruction or loss of the object of the operational activities.

A large segment of forestry research literature [1-3] has contributed to the advancement of knowledge 
from the perspective of efficiency and performance by describing performance in a technical and statistical manner through the development of various analytical models that can be applied to forest harvesting, production-oriented dashboards, productivity surveys or by studying the impact of external economic conditions on operating costs. It is important to emphasize that the performance recorded by these types of economic entities does not always ensure the sustainability of the activity. That is why we would like this work to be a means of information and awareness regarding the protection and maintenance of this natural resource.

Effective management of forestry and forestry activities can significantly contribute to the revitalization of local, regional, national and - last but not least European economies. It is known that Romania owns 6.9 million hectares of forests, accounting for about $27 \%$ of the total forest area of the country, but this also is the largest area of virgin forests in Europe, a natural wealth systematically destroyed by illegal deforestation. The products and services offered by the forest to the population have a great economic and social value, the place of the forest economy in the national economy being illustrated by the demand for these products and services on the domestic and international market. Forests play an important role not only in the production of carbon dioxide, but also in the production of biomass and through the potential that they have in the field of renewable energy.

Thus, in recent years, more and more entrepreneurs tend to develop a business in the field of forestry and forestry exploitation because Romanian forests express great potential in the supply of wood products for industrial and energy use, non-food wood products, environmental and social services $[4,5]$. In this context, the use of forests allows for the use of resources with effects on employment, reducing the marginalization and depopulation of rural areas with positive ecological repercussions.

In Romania, the forestry sector and forestry services are characterized by a complex and articulated structure in relation to the entities operating in this field; in fact, the name of the administrative forestry unit and forestry enterprise refers to the entrepreneurial activities of these different sectors, organized in a diverse manner, which include not only the firms that deal with the actual maintenance of forests and other forestry activities, but also forest exploitation companies, companies collecting non-timber forest products from spontaneous flora and other firms that manage forestry-related services.

Of these, the administrative forestry units are the most widespread in all regions of Romania, registering a significant occupational rate; there are also many small and micro-enterprises belonging to the agricultural, craft, or commercial sectors. Therefore, it is a whole ensemble, not very clearly defined, quite composite, and for activities and results obtained in terms of professionalism, labour productivity, safety, administrative regularity and classification of activities.
One of the main objectives of the European Union's rural development policy is to support companies operating in the agro-forestry sector in order to increase their competitiveness [6]. In Romania, in order to carry out forestry or logging activities, companies and administrative forestry units must comply with the provisions of the Forest Code, as well as with other normative acts elaborated upon by parliament or the Ministry of the Environment.

In this context, the aim of the paper is first of all to analyze the impact of these enterprises on sustainable development as defined in the EU Agenda. The model of reduced inequalities permit us to achieve a new perspective in the sustainability field by improving management quality goals [7]. Even though forest resources are limited, a more precise and smart organization of forestry activities leads to the improvement of their means of consumption, thus creating a sustainable and stable framework influenced by both human and natural factors $[8,9]$

The economic indicators of productivity and performance emphasized within the Forest Directorates refer to the turnover achieved or proposed to be achieved, gross profit, regeneration of forests, care and management of the forest stands, realization of the annual program of investment from the accessibility fund, realization of the annual program of investments from their own funds and maintenance of the certified forests share. The evolution of turnover and gross profit is affected by several factors that increase or decrease these indicators [10]. These aspects should be improved by analytical budgeting, which could increase economic efficiency $[11,12]$. If we take into account only incomes, the amount of wood sold in a year influences these indicators most, although we can see that the variation from year to year is not very large and that these differences may also arise from the incomes obtained from other forest products, such as forest fruits, mushrooms, medicinal plants, game meat or different forestry services such as forest protection, tree stamping or services for the drawing up of accompanying approvals of wood, hunting services with related permits or income from the imputation of logs, penalties, fines, etc. To this end, the need for new integrated territorial planning, based on sustainable local development and a close relationship between regional planning and the productive process, is becoming increasingly stringent.

In fact, according to recent scientific guidelines, spatial planning objectives can be summarized from this perspective. Therefore, the realization of social and economic functions accompanied by the use of forest products and services must not exceed the reproductive and restoration capacities of forest ecosystems. The main goal of the implementation of the concept of the integral value of forest resources consists of the complex and sustainable valorization of the respective resources, improving the policy framework in the field, assessing, and preventing and combating harmful and destructive effects on the environment and human activities [13-16]. 
Due to the transdisciplinary character of our paper, it is important to note that it is necessary to have detailed knowledge of the legal framework regulating the activity of the enterprises operating in the field of forest exploitation or forestry, of the EU requirements and objectives imposed on member countries on the development of sustainability and - last but not least - of coherent understanding and interpretation of the performance indicators registered by these companies that can influence in a profound and significant way the sustenance or, on the contrary, can signal a series of threats that could degrade the environment.

In the Report on EU Action for Sustainability of June 2017, art. 14 [17] emphasizes the important role of sustainable production and the use of timber and other forestry materials such as cork and wood-derived products, including textile fibers, for the development of some sustainable economic models and the creation of green jobs, and art.17 focuses on the importance of having a common vision and a framework for action for all member states, with a particular focus on the main driving forces of sustainable agricultural development, such as sustainable resources and climate policies.

The prospects of the forestry market and the policies that have been addressed to it have demonstrated a great deal of dynamism lately, stirring the interest of many researchers. Thus, according to Pettenella [18], as a consequence of this development, which can be found both in Italy and in the European context, the forestry sector, once completely residual in terms of agriculture, is increasingly becoming a key element of rural development strategies. The dynamism of enterprises in this field is also reflected by the presence of a fleet of newly developed vehicles. However, most important are the significant capital investments [19, 20]. The analysis of the activities of private and public actors and the management of the ecosystem services of the Tunisian forests and comparison of the results with those in Italy, Portugal and Turkey was analyzed in a comprehensive analytical study by Hasnaoui and Krott [21]. The theme of the benefits that the mountain forest offers in terms of its social and multifunctional advantage on the entire environment and in general on its benefits over the entire community has been highlighted by many researchers over time [22-25].

\section{Literature Review}

Within this section, the authors have created a link between the requirements and priorities for a sustainable development of the European Agenda 2030 and the evolution of financial economic indicators that reflect the performance of entities operating in the forestry field. It was quite difficult to do this research, especially since in Romania we did not find reference works that are focused on those directions described above. This is why we pursued a thorough study of the specialty foreign literature. The business model of entities operating in the field of forestry and other similar forestry activities must be the guarantor of sustainable development, as required by Agenda 2030. Thus, the first part of this section studied the most relevant works on sustainable development (which circumscribe the theme of the study), indicators and models of sustainability, and in the second part we studied the link between company performance and sustainable development.

\section{Performance Versus Sustainability}

Lately, a particular focus has been noticed on exploring the connection between performance and sustainability. In Malesios's point of view, sustainability is seen as the key to long-term business planning in order to facilitate the affinities of performance and to make improvements for the common good [26]. Therefore, the turnover and business growth indicators express the relationship between sustainability and the financial performance of SMEs [27, 28].

According to other studies [29, 30] better financial performance also entails a surplus of resources that can be invested in sustainability activities and initiatives. This means that firms that register better performances could imply a higher standard of integrating corporate sustainability. Some researchers [31-34] have concluded that there is no negative link between environmental sustainability of the supply chain and financial performance. The same idea is found in some recent studies [32, 35] that have demonstrated the same thing - especially that firms that have only symbolically engaged in corporate social responsibility have failed in improving their financial performance.

Although over time numerous studies have embraced some other approaches in order to describe the relationships that exist between businesses and society, corporate sustainability (CS) has become one of the most used concepts that describes the connection between sustainable development and a company's activity [36-39].

According to Barney [40], a company's resources refer to all its assets, performances, organizing processes, features, data, knowledge, etc. that are managed by a company that allows that company to design and implement strategies in order to generate profit and improve efficiency and effectiveness. In order to sustain a competitive advantage, the resources of a business need to be valuable, rare, and imperfect in order to duplicate and not to be used as strategic substitutes for those resources that are valuable, yet neither rare nor imperfect to duplicate [40].

\section{The Relationship between Financial Performance Indicators in Foresty Domain and Sustainability}

The convergence of those two theoretical trends basically suggests that the CSP may bring about benefits through the improvement of the relationship with the stakeholders, through creating the competitive 
Table 1. Previous study regarding economic sustainability, environmental sustainability and social sustainability performance.

\begin{tabular}{|c|c|c|c|}
\hline Author & $\begin{array}{l}\text { Phenomenon } \\
\text { studied }\end{array}$ & Aim & Results/Conclusions \\
\hline $\begin{array}{l}\text { Meadows } \\
\text { et. al [43] }\end{array}$ & $\begin{array}{l}\text { Sustain- } \\
\text { ability vs } \\
\text { environmental } \\
\text { deterioratio }\end{array}$ & $\begin{array}{c}\text { Examination the five basic factors that de- } \\
\text { termine and, in their interactions, ultimately } \\
\text { limit growth on this planet-population in- } \\
\text { crease, agricultural production, non-renewa- } \\
\text { ble resource depletion, industrial output, and } \\
\text { pollution generation }\end{array}$ & $\begin{array}{l}\text { In the event the actual tendencies of the growth of the } \\
\text { world population, industrialization, food production and } \\
\text { the resources' depletion will continue to manifest, the } \\
\text { maximum limits will be achieved in the following } 100 \\
\text { years. The solution that was argued by the authors of } \\
\text { the study refers to the transition from the growth itself } \\
\text { towards a global balance }\end{array}$ \\
\hline $\begin{array}{l}\text { Meadows } \\
\text { et. al [44] }\end{array}$ & $\begin{array}{l}\text { Sustainabil- } \\
\text { ity: the Next } \\
\text { Revolution }\end{array}$ & $\begin{array}{l}\text { Analyze the existence of a sustainable } \\
\text { system and sustainability itself as the next } \\
\text { revolution that follows the first two ones, } \\
\text { namely agriculture and industry }\end{array}$ & $\begin{array}{l}\text { The results show that sustainability's revolution can } \\
\text { generate huge profits as well as losses and, in the event } \\
\text { it does take place, it will be organic and evolutionary, } \\
\text { it will stem from a vision, understanding, experiments } \\
\text { and common actions of millions of billions of people, } \\
\text { organizations and countries. }\end{array}$ \\
\hline $\begin{array}{l}\text { Cieśl el al. } \\
\quad[45]\end{array}$ & $\begin{array}{l}\text { Sustainable } \\
\text { Development }\end{array}$ & $\begin{array}{l}\text { Designing a "synthetic measure thanks to } \\
\text { which changes in sixteen regions of Poland } \\
\text { between } 2003 \text { and } 2013 \text { are presented with } \\
\text { respect to the level of sustainability based } \\
\text { on three components: social, economic, and } \\
\text { environmental order". }\end{array}$ & $\begin{array}{l}\text { The performed analysis showed that "the indicators of } \\
\text { sustainable development, both for individual regions } \\
\text { and for the whole of Poland, had not changed signifi- } \\
\text { cantly in the determined two moments of time (2003 } \\
\text { and 2013)". }\end{array}$ \\
\hline $\begin{array}{c}\text { Büyüközkan } \\
\& \text { Karabulut } \\
{[46]}\end{array}$ & $\begin{array}{l}\text { Sustainability } \\
\text { performance }\end{array}$ & $\begin{array}{l}\text { Provide a structured "overview of sustaina- } \\
\text { bility performance evaluation related publi- } \\
\text { cations and to document the current state of } \\
\text { literature, categorize publications, analyze } \\
\text { and link trends, as well as highlight gaps } \\
\text { and provide research recommendations". }\end{array}$ & $\begin{array}{l}\text { The results suggest "that sustainability performance } \\
\text { evaluation models shall be more balanced, suitable } \\
\text { criteria and their interrelations shall be well defined and } \\
\text { subjectivity of qualitative criteria inherent to sustain- } \\
\text { ability indicators shall be considered". }\end{array}$ \\
\hline $\begin{array}{l}\text { Marshall, \& } \\
\text { Toffel. [47] }\end{array}$ & $\begin{array}{l}\text { A Sustainabil- } \\
\text { ity Hierarchy }\end{array}$ & $\begin{array}{c}\text { Propose a Sustain ability Hierarchy to struc- } \\
\text { ture a broad array of issues that have been } \\
\text { associated with sustainability. }\end{array}$ & $\begin{array}{l}\text { Results suggest that for sustainability to become a more } \\
\text { meaningful concept, the many worthy issues in the } \\
\text { fourth category (values, beliefs, and aesthetic prefer- } \\
\text { ences) should not be considered sustainability concerns. } \\
\text { Implications for companies, policy makers, and scien- } \\
\text { tists are discussed }\end{array}$ \\
\hline $\begin{array}{l}\text { Hanaaes et } \\
\text { al. }[48]\end{array}$ & $\begin{array}{l}\text { Sustainability } \\
\& \text { innovation }\end{array}$ & $\begin{array}{l}\text { Find if sustainability approaches correlate } \\
\text { with top competitive performance. }\end{array}$ & $\begin{array}{l}\text { Study shows that Businesses are increasing their } \\
\text { investments and attention; a "two-speed" sustainability } \\
\text { landscape is emerging, with a gap between "embracers" } \\
\text { and non-embracers; the C-suite is increasingly on board, } \\
\text { but not for environmental reasons.. }\end{array}$ \\
\hline $\begin{array}{l}\text { Malesios et } \\
\text { al. . [26] }\end{array}$ & $\begin{array}{l}\text { Sustainability } \\
\text { vs financial } \\
\text { performance }\end{array}$ & $\begin{array}{l}\text { Assessing the relationship between social, } \\
\text { environmental and operational practices and } \\
\text { performance with financial performance }\end{array}$ & $\begin{array}{l}\text { Resuls show a "significant positive association between } \\
\text { certain items of sustainability and firms' financial } \\
\text { performance is identified as we found that different } \\
\text { indicators of sustainability display associations with } \\
\text { the two economic indicators and adoption of the former } \\
\text { may influence SME performance". }\end{array}$ \\
\hline $\begin{array}{l}\text { Hussain et } \\
\text { al . [30] }\end{array}$ & $\begin{array}{l}\text { Corporate } \\
\text { governance vs } \\
\text { sustainability } \\
\text { performance }\end{array}$ & $\begin{array}{l}\text { Investigating the "relationship between cor- } \\
\text { porate governance and the triple bottom line } \\
\text { sustainability performance through the lens } \\
\text { of agency theory and stakeholder theory". }\end{array}$ & $\begin{array}{l}\text { They "identify which governance mechanisms foster } \\
\text { triple bottom line performance, also revealing that some } \\
\text { mechanisms fit on". }\end{array}$ \\
\hline $\begin{array}{l}\text { Pohoață } \\
{[50]}\end{array}$ & $\begin{array}{c}\text { Economic phi- } \\
\text { losophy and } \\
\text { sustainable } \\
\text { development } \\
\text { policy }\end{array}$ & $\begin{array}{l}\text { Synthesis on the issues by adding to the } \\
\text { economic analysis consistent references on } \\
\text { the field of biology, philosophy, sociology, } \\
\text { ethics, morals, law. }\end{array}$ & $\begin{array}{l}\text { Study suggests the introduction of the sustainable } \\
\text { development syntagm as part of the economic science } \\
\text { vocabulary. The authors consider development, no mat- } \\
\text { ter which side we look at - economic, social, biological, } \\
\text { cultural, philosophical, etc. - can not claim the neutrality } \\
\text { of politics }\end{array}$ \\
\hline
\end{tabular}


Table 1. Continued.

\begin{tabular}{|c|c|c|c|}
\hline Author & $\begin{array}{l}\text { Phenomenon } \\
\text { studied }\end{array}$ & Aim & Results/Conclusions \\
\hline $\begin{array}{l}\text { Hajdúchová } \\
\text { et al. [51] }\end{array}$ & $\begin{array}{c}\text { Forest } \\
\text { enterprises' } \\
\text { performance }\end{array}$ & $\begin{array}{l}\text { The paper deals with determining forest } \\
\text { enterprises' performance in Slovakia. The } \\
\text { authors draw attention to the general meth- } \\
\text { ods used for performance analysis based on } \\
\text { the analysis of the enterprise's profitability. } \\
\text { The paper contains goal settings and meth- } \\
\text { ods for performance analysis and highlights } \\
\text { the specific application of these methods in } \\
\text { forest enterprises as well as difficulties in } \\
\text { obtaining input data. }\end{array}$ & $\begin{array}{l}\text { "The results show that the highest performance of } \\
\text { forest enterprises was noted in the years of } 2011 \\
\text { and } 2014 \text {. The more detailed analysis of perform- } \\
\text { ance - based on the relation between the analytically } \\
\text { determined input and the material output of the } \\
\text { transformation process confirmed that the increased } \\
\text { performance was triggered by intensified timber } \\
\text { harvesting. Recommendations and conclusions for } \\
\text { the performance analysis of forest enterprises as well } \\
\text { as the evaluation of the performance of forestry in } \\
\text { Slovakia are presented in the last part". }\end{array}$ \\
\hline $\begin{array}{c}\text { Macqueen } \\
\text { [52] }\end{array}$ & $\begin{array}{l}\text { Profitable and } \\
\text { sustainable } \\
\text { forest } \\
\text { enterprises }\end{array}$ & $\begin{array}{l}\text { This paper draws on "international experi- } \\
\text { ence to introduce the three main enabling } \\
\text { conditions for profitable and sustainable } \\
\text { community forest enterprises: clear com- } \\
\text { mercial forest rights, strong social organisa- } \\
\text { tion and competitive business skills". }\end{array}$ & $\begin{array}{l}\text { The study highlights the fact that if countries want to } \\
\text { develop profitable and sustainable community forestry } \\
\text { enterprises } \\
\text { both to help meet market demand, avoid deforestation } \\
\text { and reduce the poverty they have consider seriously } \\
\text { how to: ensuring community forestry rights for commu- } \\
\text { nities; facilitating stronger social organizations among } \\
\text { Community producer groups; assistance in developing } \\
\text { competitive business skills for those communities } \\
\text { groups }\end{array}$ \\
\hline
\end{tabular}

Source: The authors.

sustainable advantages and through the improvement of the company's reputation. This will have a positive impact of the CSP on the FP [39]. According to Artiach et al. [41], a company's decision to invest in sustainable actions is influenced by the stakeholders. If the stakeholders have control over those resources that are very important for the company, then it is highly likely that companies will satisfy those stakeholders' demands. The nature of the company's reaction to stakeholder pressure will depend on its strategic positioning and its financial performance. Thus, during those periods with low profits and high debts, the financial stakeholders will gain over the social pressures. On the other hand, economic performance will have an impact on the way companies will allocate financial resources for expensive sustainable actions.

Throughout time, such discussion themes have generated a specific interest in the academic media. This interest has been rendered by a consistent group of theories that have been the result of numerous research and studies where the seemingly elusive concept of sustainability comprises a broad meaning. Nevertheless, most approaches have connected sustainability with its minimum negative ecological impact and have focused less on its economic and social aspects.

In order to support the objective of our study by taking into account the specialty literature, we analyzed the most important studies that focused on the connection between performance and sustainability. The reason for choosing these papers was the research field and the notoriety of research journals. We mainly relied on Reyes' methodology [42] in order to design the table below. The results of the previous studies are presented in Table 1.

The idea of a sustainable economic system has been accepted and further developed, with special attention to the qualitative aspect of its development in the detriment of its physical expansion [43]. According to Meadows et al., a sustainable world would require the existence of rules, laws, standards, boundaries, connections and social constraints for companies and individuals [43].

In many studies, the concept of sustainability is derived and analyzed from the perspective of terms like: social sustainability, corporate social responsibility (CSR), corporate social performance (CSP) or corporate financial performance (CFP), as well as the links between them. Spangenberg and Bonniot [53] consider that in the context of the current economy, more and more companies have understood the importance of CSR on their business, as well as on sustainability despite of their size or country of origin.

Other Wang research [54, 55] shows that if CSR policies become a common practice in a particular industry, recognition from independent third parties shows that CSR initiatives will enhance business performance. It is also noted here that companies pursue stable profitability and sustainability and communicate with shareholders about the benefits of CSR in terms of financial performance.

Bernard [56] argues that the performance of corporate CSR policies and actions is corporate sustainability performance (CSP). CSR relies mainly on company direction, policies and actions, while CSP is based on how effective those actions are in terms of 
economic, social and environmental change. Xiao's [57] research provides new perspectives on the contingency relationship between CSP and CFP. This shows that the positive financial effect of the CSP is moderately negative by nationwide sustainability performance.

\section{Material and Method}

As we have previously highlighted, taking into account its multidimensional nature, sustainability has become a process that cannot be rendered through a single feature. Integrating this concept within the business practice results in the direct influence on both corporate sustainability performance (CSP) and financial performance (FP). This represents the main trend of analysis we are focusing on in our research. The analysis carried out in this study aims to evaluate the performance of 200 entities operating in the northeastern region of Romania and assess their potential to contribute to sustainable development, through the adoption by the member states of the 2030 agenda for sustainable development (see Fig. 6). One of the European objectives in terms of sustainability is energy efficiency - namely the reduction of greenhouse gas emissions, in a percentage of $20 \%$, and at the same time coverage of energy demand in the EU, also in a percentage of $20 \%$ from renewable sources. Companies in the forestry sector have understood and accepted the idea of continuous investment in actions that promote and support sustainable development. Sustainable development means, we believe, that companies run their businesses by understanding both their economic and social roles.

Sustainability, in the sense of Agenda 2030 [58], aims to achieve welfare for all European citizens on the three equal pillars of sustainable (social, environmental and economic) development. In the field of the environment, the companies selected for the study represent, for the northeast region, the first 200 most important companies active in the "green area," respectively forestry.

The average turnover in the forestry sector for the 200 analyzed companies in the period 2009-2017 was $1,700,000$ lei, increasing toward the end of the period (2016), when the average turnover for the 200 entities reached RON 2,250,000. At the level of the profitability of the activity, by reporting the gross profit, oscillating developments at the level of the 200 entities are observed, the average net profit ratio reported during $2009-2017$ was 130,500 lei, respectively $7 \%$ of the average turnover. The period with high profitability is 2014-2015, when the average annual profit reached 170,180 lei, i.e., $35 \%$ more than the average of the period.

A $16 \%$ tax on the net profit average is a significant aspect in terms of sustainable development, requiring the attention of qualified bodies to provide tax incentives for this sector, so that investments can generate an

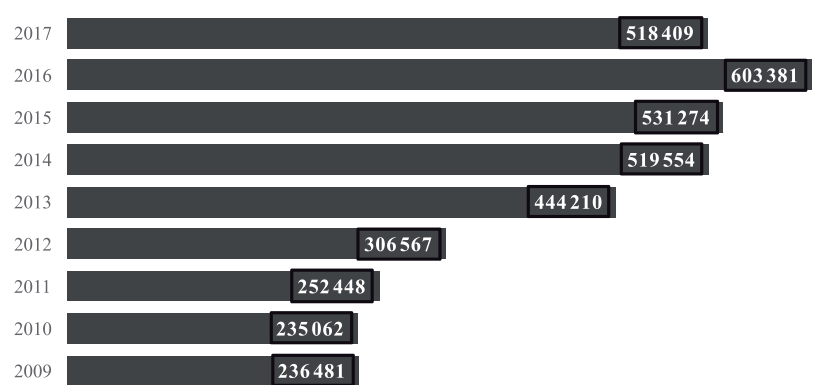

Fig. 1. The average annual value of the fixed assets held by the 200 entities $\left(\right.$ lei $\left.^{1}\right)$.

Source: An adaptation based on the information found on: [59].

increase in the forest fund and a better allocation of resources in the sector. A first measure was granted by tax authorities for micro-enterprises that currently apply the 3\% income tax rate. This share is reduced for the micro-enterprises with several employees to up to $1 \%$, some tax incentives being also registered for authorized individuals for which the tax rate of $10 \%$ was applied, and at the same time the increase of the profit tax threshold according to the turnover, this measure being for the benefit of the former taxpayers. The value of immobilized assets is extremely fluctuating among the companies analyzed, asset capitalization poles on average being highlighted, at the level of over 4,000,000 lei (for 4 companies) and the held value represents 8 times the average value of assets managed by the 200 entities, with the indication that the average growth trend of fixed assets is constantly positive, see Fig. 1.

The liquidity of the assets held by the companies analyzed is average, with an average asset liquidity of $53 \%$ being recorded at the level of the 200 entities (see Fig. 2).

In terms of the workforce used, a relatively constant average is observed with a left-right unitary movement of \pm 1 at the level of 9 employees for the 200 entities analyzed. However, the differences within the sample are significant, a number of 8 entities using an average of 30 employees, while the remaining 42 entities use an average workforce of 5 people, which brings the difference between the two poles of the sample to a value more than 6 times.

To analyze the economic performance of forestry holdings in the northeastern region of Romania and to analyze their ability to provide the sustainable development objectives for the year 2030, we used the segmentation of the sample on 3 classes of activities according to the NACE code, namely: NACE: 210 - Forestry and other forestry activities;

1 All values throughout this paper are denominated in the national currency of Romania, the leu: 1 euro $=4.6283$ lei (according to the exchange rate of the Romanian National Bank on 31.07.2018). 


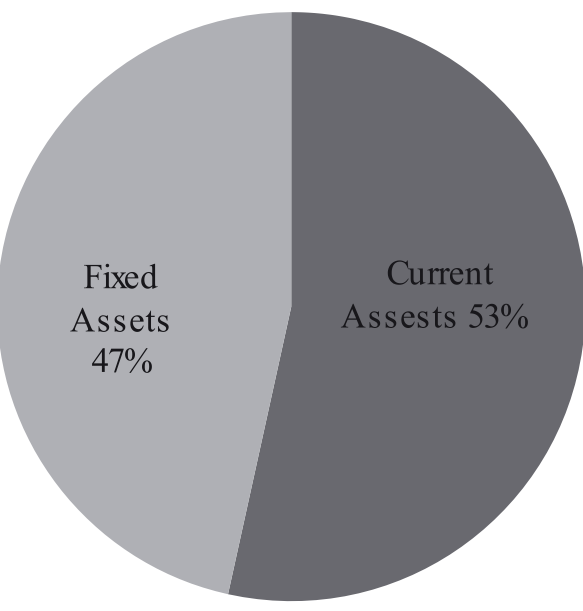

a Current Assests $\square$ Fixed Assets

Fig. 2. Average asset liquidity. Source: An adaptation based on the information found on: [59].

NACE: 220 - Forestry exploitation; NACE: 230 - Collection of non-timber forest products from spontaneous flora and 240 - Services incidental to forestry (see Table 2).

A significant advance of sustainable development for the forestry sector (CAEN 210) is found from the presented data, especially in terms of the commercial capacity shown by the turnover $(\Delta+50 \%$ from the general average). The following branch, namely the forest exploitation branch (CAEN 220), decreased the turnover by $-19 \%$ compared to the general average. The last branch, the collection of non-timber forest products from the spontaneous flora (CAEN 230) and forestry services activities (CAEN 240), was the most disadvantaged in terms of sustainable development, having a commercial deficit of up to $-53 \%$ compared to the general average. Regarding net profit, the trend is similar. The first branch, namely the forestry sector, shows a $231 \%$ net profit growth compared to the general average, and the latter will have a successive decrease: the second, with $-66 \%$, the third decreasing by $-101 \%$.

This trend is also found among the indicators reflecting debts, current assets, equity, number of employees, RCN (net capitalization rate) and RF (financial rate) (see Table 3). Fixed assets experienced a slight increase for the $2^{\text {nd }}$ branch, compared to the first branch $(0 \%)$, registering a value of $5 \%$ compared to the general average. The last branch suffered a drastic decline in fixed assets of up to $-68 \%$ compared to the general average. The rotational speed (v) of circulating assets represents a successive chronological increase for the three branches.

In order to evaluate the qualitative parameters of sustainable development, we developed a statistical, regressive model based on the smallest squares method, a model in which the main financial and balance sheet indicators are correlated with financial ratios to assess the financial or commercial sustainability of companies as defined by general, sectoral averages and the overall average of the 200 entities surveyed. The data obtained were integrated into an econometric model through GRETL statistical software, version 2019; the following hypotheses $(\mathrm{H})$ were formulated:

H1: The value of the average financial indicators reflects the general trend of each activity category for which they are calculated.

Table 2. Statistical data calculated on average for the economic indicators obtained by the companies in the sample during the period 2008-2017.

\begin{tabular}{|c|c|c|c|c|c|}
\hline Indicator** & $\begin{array}{c}\text { Symbol/ } \\
\text { formula }\end{array}$ & $\begin{array}{c}\text { Overall average } \\
\text { NACE }\end{array}$ & $\begin{array}{c}\text { Average } \\
\text { NACE 210 }\end{array}$ & $\begin{array}{c}\text { Average } \\
\text { NACE 220 }\end{array}$ & $\begin{array}{c}\text { Average } \\
\text { NACE 230-240 }\end{array}$ \\
\hline Turnover & $\mathrm{T}$ & 1.676 .000 & 2.509 .000 & 1.350 .000 & 781.000 \\
\hline Net income (NI) & NI & 128.000 & 424.000 & 43.000 & -1.000 \\
\hline Debts & D & 552.000 & 677.000 & 531.000 & 205.000 \\
\hline Fixed assets & FA & 407.000 & 408.000 & 428.000 & 129.000 \\
\hline Current assets & AC & 468.000 & 853.000 & 344.000 & 139.000 \\
\hline Equity & EQ & 308.000 & 555.000 & 235.000 & 63.000 \\
\hline Number of employees & NE & 9 & 13 & 9 & 2 \\
\hline Rcn $(\%)$ & NI/T *100 & $7,64 \%$ & $16,90 \%$ & $3,19 \%$ & $-0,13 \%$ \\
\hline Rf & NI/EQ*100 & $41,56 \%$ & $76,40 \%$ & $18,30 \%$ & $-1,59 \%$ \\
\hline La & AC/FA*100 & $114,99 \%$ & $60,27 \%$ & $80,60 \%$ & $62,93 \%$ \\
\hline Rai & T/FA*100 & $411,79 \%$ & $614,95 \%$ & $315,42 \%$ & $605,43 \%$ \\
\hline v & T/AC & $358,12 \%$ & $294,14 \%$ & $392,44 \%$ & $561,87 \%$ \\
\hline
\end{tabular}

Source: An adaptation based on information found in [59]

* Data disseminated by sectors of activity, according to NACE 
Table 3. Variational analysis of multiannual sectoral averages in relation to general averages.

\begin{tabular}{|c|c|c|c|c|}
\hline Indicator* & Symbol/formula & Overall average NACE & $\begin{array}{c}\text { Average } \\
\text { NACE } 210\end{array}$ & $\begin{array}{c}\text { Average } \\
\text { NACE 220 }\end{array}$ \\
\hline Turnover & $\mathrm{CA}$ & $1,676,000$ & $2,509,000$ & $1,350,000$ \\
\hline Net income (NI) & $\mathrm{PN}$ & 128,000 & 424,000 & 43,000 \\
\hline Debts & $\mathrm{D}$ & 552,000 & 677,000 & 531,000 \\
\hline Fixed assets & $\mathrm{AI}$ & 407,000 & 408,000 & 428,000 \\
\hline Current assets & $\mathrm{AC}$ & 468,000 & 853,000 & 344,000 \\
\hline Equity & $\mathrm{CP}$ & 308,000 & 13 & 235,000 \\
\hline Number of employees & $\mathrm{NS}$ & 9 & $16.9 \%$ & 9 \\
\hline $\mathrm{R}_{\mathrm{c}}(\%)$ & $\mathrm{PN} / \mathrm{CA} * 100$ & $7.64 \%$ & $76.40 \%$ & $3.19 \%$ \\
\hline $\mathrm{R}_{\mathrm{f}}$ & $\mathrm{PN} / \mathrm{CP} * 100$ & $41.56 \%$ & $60.27 \%$ & $18.30 \%$ \\
\hline $\mathrm{L}_{\mathrm{a}}$ & $\mathrm{AC} / \mathrm{AI} * 100$ & $114.99 \%$ & $614.95 \%$ & $80.60 \%$ \\
\hline $\mathrm{R}_{\mathrm{ai}}$ & $\mathrm{CA} / \mathrm{AI} * 100$ & $411.79 \%$ & $315.42 \%$ \\
\hline
\end{tabular}

Source: An adaptation based on information found in [59]

$*$ All values are denominated in the national currency of Romania, the Leu; 1 Euro $=4.6283$ Lei according to the exchange rate of the Romanian National Bank on 31.07.2018

H2: The average value of the calculated balance indicators is the beneficiary capacity of the 200 entities that are part of the sample and reflects the average economic capacity of entities to activate on the related market.

H3: Financial ratios are all the greater as the beneficiary capacity is higher, aiming to maximize according to the sustainable development factors, provided that the growth rate of the stable business is maintained.

H4: The liquidity of the assets on average is higher than the liquidity of the assets per category of activity, on the conditions of a portfolio of assets differentiated according to the type of fixed assets required to carry out the activities of each branch of the analyzed profile

H5: The rotational speed of circulating assets is even higher as the turnover is lower, where companies need to ensure business sustainability by the extra turnover.

The model equation determined by the smallest square method is as follows:

$$
\mathbf{V}=\sum_{i=1}^{n} a i * v_{k m_{i+\varepsilon}}
$$

...where $\mathrm{V}$ is the vector-dependent variable for the entities being analyzed,

$$
\text { In which } \mathbf{V}=\left(\begin{array}{c}
C A \\
P N \\
D \\
A I \\
A C \\
C P \\
N S \\
R c n \\
R f \\
L a \\
R a i \\
v
\end{array}\right)
$$

$\mathrm{Vi}$ - regressors calculated for each branch of activity in matrix format as the dependent variable

$a_{i}-$ coefficients of regression

$\varepsilon$ - residual constant

The transposition of the average indicators into the GRETL statistical program allowed the following regression coefficients of the above model to be obtained:

$$
\begin{gathered}
\mathrm{v} 1=+0,250 * \mathrm{v} 2+0,636 * \mathrm{v} 3+0,242 \\
* \mathrm{v} 4(0,00460)(0,0104)(0,0183) \\
\mathrm{n}=13, \mathrm{R} \text {-squared }=1,000 \\
\text { (standard errors in parentheses) }
\end{gathered}
$$

\section{Results and Discussion}

The statistical tests of homogeneity and representativeness of the model show that the data are statistically highly correlated, the $p$ values of the regression variables being less than 0.0001 and the value $\mathrm{R} 2$ being equal to 1 , which shows the high degree of statistical significance of the model (see Table 4).

Tests for residual normality are valid under the condition that the error is normally distributed with the Chi-square test with $\mathrm{p}$-value $=0.5$, and the heteroscedasticity test reveals that the phenomenon is not present within the model, the model being valid and significant for the studied phenomenon.

Residue Normality Test -

Null hypothesis: The error is normally distributed

Statistical test: Hi square $(2)=3.74152$

with $\mathrm{p}$-value $=0.154006$

Chow test for structural rupture at observation 7-

Null hypothesis: no structural rupture 
Table 4. Model 1: OLS using observations 1-13.

\begin{tabular}{|c|c|c|c|c|c|}
\hline & \multicolumn{4}{|c|}{ Dependent variables: v1 } & \\
\hline & Coefficient & Std. Error & t-ratio & p-value & \\
\hline v2 & 0,250491 & 0,00460334 & 54,42 & $<0,0001$ & $* * *$ \\
\hline v3 & 0,635531 & 0,0103561 & 61,37 & $<0,0001$ & $* * *$ \\
\hline v4 & 0,242353 & 0,0182882 & 13,25 & $<0,0001$ & $* * *$ \\
\hline Mean dependent var. & \multicolumn{2}{|c|}{272232,3} & \multicolumn{2}{|c|}{ S.D. dependent variable } & 469588,9 \\
\hline Amount of squares of residues & \multicolumn{2}{|c|}{75976257} & \multicolumn{2}{|c|}{ Standard Error of Regression } & 2756,379 \\
\hline Uncentered R-squared & \multicolumn{2}{|c|}{0,999979} & \multicolumn{2}{|c|}{ Centered R-squared } & 0,999971 \\
\hline $\mathrm{F}(3,10)$ & \multicolumn{2}{|c|}{158362,0} & \multicolumn{2}{|c|}{ P-value(F) } & $1,12 \mathrm{e}-23$ \\
\hline Log-likelihood & \multicolumn{2}{|c|}{$-119,7226$} & \multicolumn{2}{|c|}{ Akaike criterion } & 245,4452 \\
\hline Schwarz criterion & \multicolumn{2}{|c|}{247,1400} & \multicolumn{2}{|c|}{ Hannan-Quinn } & 245,0968 \\
\hline
\end{tabular}

Source: Elaborated with the GRETL statistical software version 2019

Statistical test: $F(4,6)=0,820051$

with p-value $=\mathrm{P}(\mathrm{F}(4,6)>0,820051)=0,55684$

The Breusch - Pagan Test for Heteroskedasticity -

a)

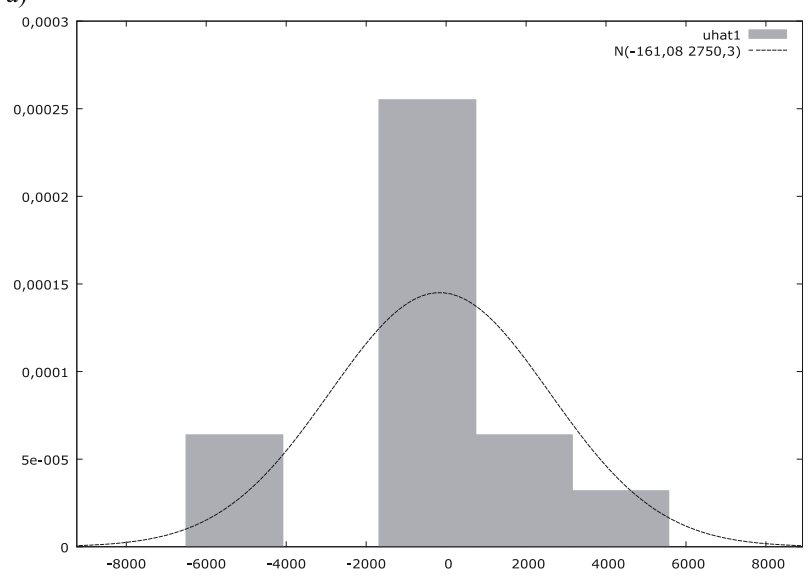

b)

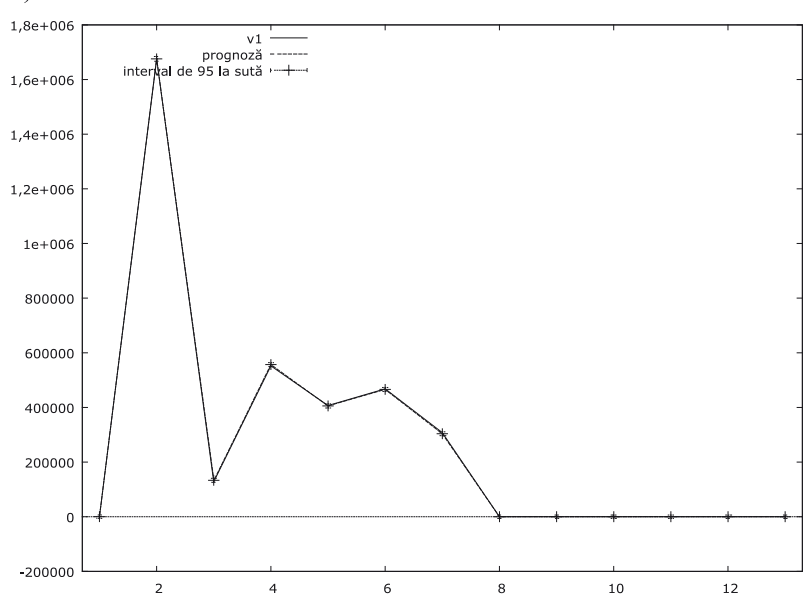

Fig. 3. Statistical data distribution graphs: a) histogram of errors and b) forecast chart. Source: Elaborated upon with GRETL statistical software version 2019.
Null hypothesis: heteroskedasticity is not present

Statistical test: $\mathrm{LM}=9,57393$

with $\mathrm{p}$-value $=\mathrm{P}($ Hi square $(3)>9,57393)=0,0225578$

The distribution charts and the forecasting chart on the confidence interval of $95 \%$ indicates the accumulations of the value at the maximum point of the Gaussian curve and the relative colinity of the data, predicted with the actual evolution of v1, as follows (see Fig. 3, Fig. 4):

Forecast evaluation statistics:

Mean Error $\quad-161,08$

Root Mean Squared Error 2417,5

Absolute Mean Error 1419,6

Mean Percentage Error $\quad-945,5$

Mean Absolute Percentage Error 957,29

Theil's U 0,00016211

Bias proportion, UM $\quad 0,0044395$

Regression proportion, UR 0,001619

Disturbance proportion, UD $\quad 0,99394$

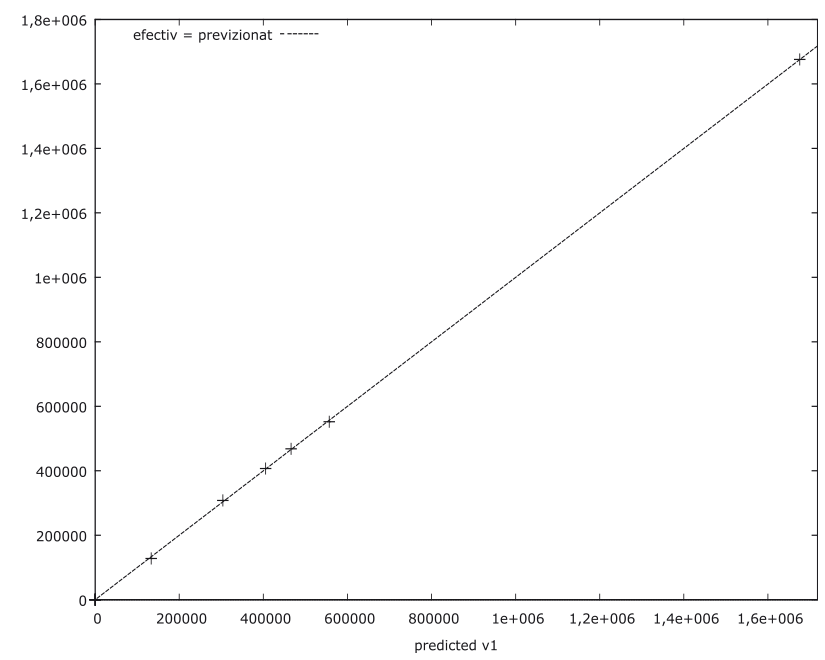

Fig. 4. Chart Q-Q plot. Source: Elaborated upon with GRETL statistical software version 2019. 


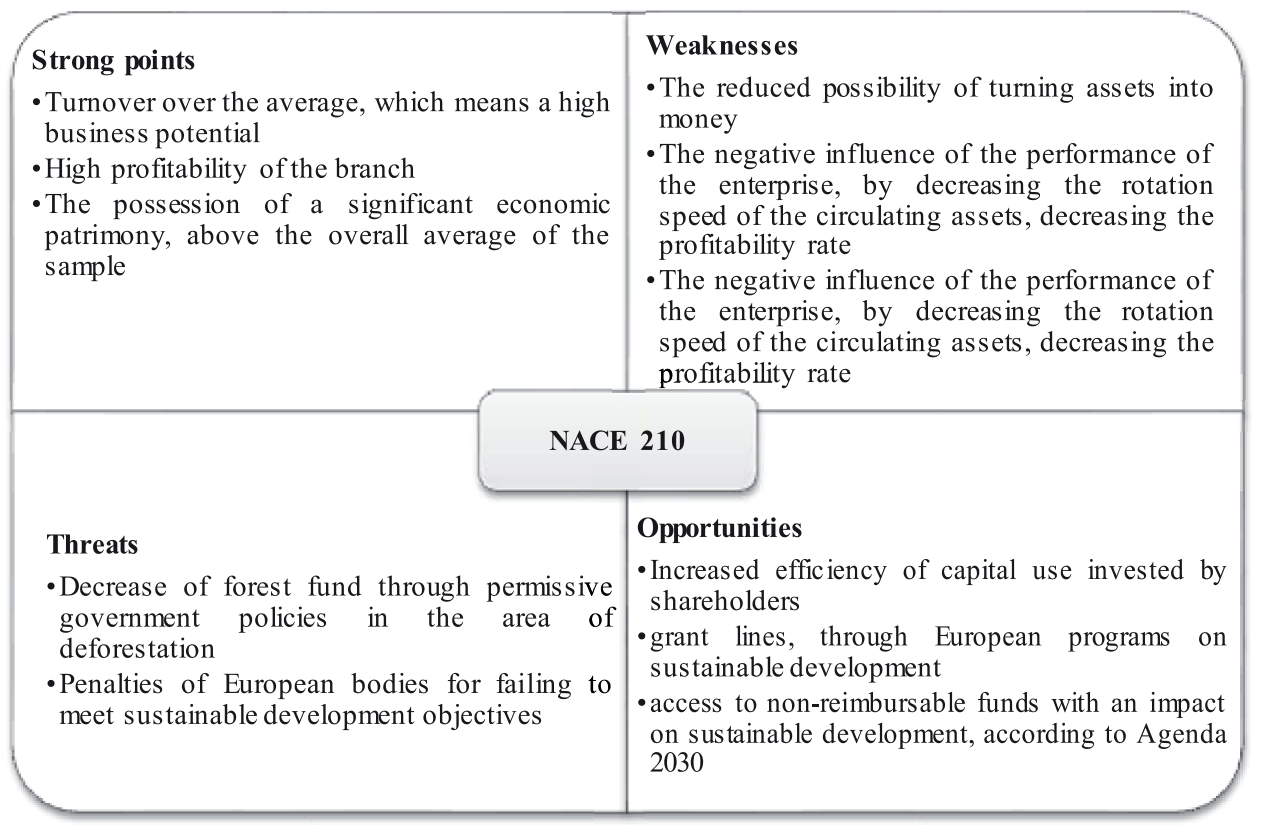

Fig. 5. Analysis of SWOT NACE 210. Source: Author's own elaboration.

The polarization of the data by the distribution to the right of the trend reveals a high degree of statistical correlation for the phenomenon studied, which demonstrates that the economic phenomenon is representative and well determined by the proposed statistical model. The model can also be successfully transposed into other segments in which the sustainable development objectives under Agenda 2030 are present, allowing for a macroeconomic impact analysis by translating the data through which the phenomenon of trade development can be studied as the main branch of sustainable development in a more elaborate way, and for longer than 10 years, which reliably assesses the trends of economic indicators evolution.
For the analyzed segment, the model allows the evaluation of disturbances by means of a comparative picture (see Fig. 5).

As we can see, the analyzed entities operating in the field of forestry and other similar forestry activities, which have a turnover above the general average, are those that contribute significantly to an increase in the efficiency of the use of capital investments in coherence with the priorities of the EU 2030 Agenda for Sustainable Development (see Fig. 6).

Unlike the first category of the entities analyzed, the ones operating in the field of forestry exploitation, which have an over-average turnover, are more concerned with the acceleration of the rotational speed of the circulating

\section{Strong points}

- High turnover on average, around the average

- Owning a portfolio of significantly immobilized assets, $5 \%$ higher than the average -Positive influence of the performance of the enterprise by increasing the rotational speed of the circulating assets, increasing the profitability rate

\section{NACE 220}

\section{Threats}

-Decrease of forest fund through permissive government policies in the area of deforestation

- Penalties of European bodies for failing to meet sustainable development objectives

\section{Weaknesses}

- a low net profit, amid what points to a low patrimonial recovery and an unfavorable net capitalization rate

- a liquidity and return on fixed assets decreased by about $25-30 \%$ below the overall average

\section{Opportunities}

- The ability to accelerate the rotation speed of circulating assets with favorable direct effects on performance indicators (benefit and rate of return)

- the possibility of appreciating the value of fixed assets

Fig. 6. Analysis of SWOT NACE 220. Source: Author's own elaboration. 


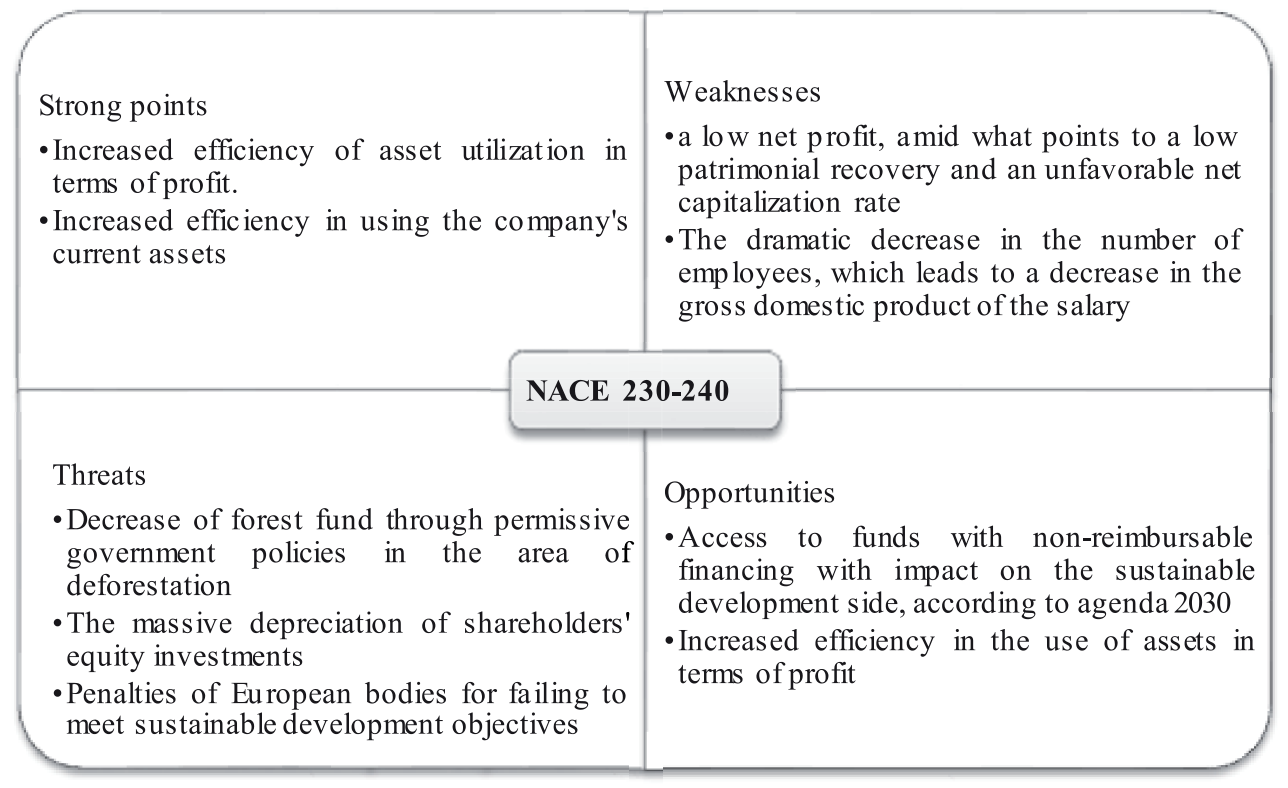

Fig. 7. Analysis of SWOT NACE 230-240. Source: Author's own elaboration.

assets with direct favorable effects on the performance indicators (benefit and rate of return), but with negative effects on the decrease of the forest fund through its administration policies, which may conflict with article No. 14 of the EU 2030 Agenda, which highlights the important role of sustainable production and use of timber and other forestry materials such as cork and wood-derived products, including textile fibers, for the development of sustainable economic models and the creation of green jobs (see Fig. 7).

The last category of companies operating in the field of collecting non-timber forest products from the spontaneous flora or practicing other services related to forestry are more profit-oriented. Even if they are exposed to obvious disruptions in terms of investment depreciation and penalties from European bodies regarding failure to meet sustainable development objectives, they benefit from the possibility of being financed by non-reimbursable funds under the EU 2030 Agenda with positive effects on the efficiency of the use of patrimonial assets.

The empirical results support the hypothesis that:

- The value of the average financial indicators reflects the overall trend of each activity category for which they are calculated.

- The average value of the calculated balance indicators is the beneficiary capacity of the 200 entities that are part of the sample and reflect the average economic capacity of the entities to activate on the related market.

- Financial ratios are all the higher as the beneficiary capacity is higher, tending to maximize according to the factors of sustainable development, provided the stable growth rate of the business.

- The liquidity of the assets on average is higher than the liquidity of assets per category of activity, under the conditions of a portfolio of assets differentiated according to the type of fixed assets necessary for the activity of each analyzed branch.

- The turnover rate of the current assets is even higher as the turnover is lower, the companies having to ensure business sustainability through the extra turnover.

We found that the entities operating in the field of forestry and other similar forestry activities that have a turnover above the general average have a significant contribution to the increase in the efficiency of the use of capital investments in accordance with the priorities of the EU 2030 Agenda for Sustainable Development.

Also, the entities operating in the field of forestry exploitation, which have an above-average turnover, are more concerned with the acceleration of the rotational speed of the circulating assets with direct favorable effects on the performance indicators (benefit and rate of return), but with negative effects on the decrease of the forest fund through its administration policies, which may conflict with article No. 14 of the EU 2030 Agenda, which highlights the important role of sustainable production and the use of timber and other forestry materials such as cork and wood-derived products, including textile fibers, for the development of sustainable economic models and the creation of green jobs.

In this study, the authors wanted to draw attention on the results of the evaluation of the success of the forest enterprises in Romania by analyzing their performance. As can be seen from the practical part of the study, many entities are oriented toward achieving financial performance rather than toward the social performance and the environment. In this study, general methodologies are used for performance analysis. Moreover, the authors highlight the specificities of forest 
production and management, as well as their impact on the performance of the forestry enterprises.

Even though some studies show that companies with sufficient financial resources are making greater efforts to improve their social and environmental performance, these investments in CSP generating favourable financial profits $[30,60]$, these community forestry companies play an increasingly important role in local reinvestment of profits to reduce poverty [52]. We belive that - especially in Romania - unfortunately, the lack of clearer regulations about forest domain has led to a real environmental disaster caused by illegal tree cuts in private forests and on private pastures. Some of these situations are caused by: undermining forestry authority in forests; some practices of intimidation starting from the political factor; malfunctions in the judiciary system; very low number of forestry staff with specific duties on forest protection; and poverty and a precarious social state of a huge population groups.

The fact that we are taking into consideration just the forestry enterprises highlights the fact that we have faced problems of measuring performance that arise from the specifics of forest management. Therefore, in this study indicators that remove the weaknesses of classical approaches are suggested for general use. At the same time, these indicators (turnover, net income, $\mathrm{R}_{\mathrm{cn}}, \mathrm{R}_{\mathrm{ai}}$ ) are considered relevant to this type of activity.

Relying on an econometric model based on the smallest squares method, we investigated the financial performance indicators of enterprises operating in the field of forestry and forestry exploitation in the northeastern Romania and their effects on sustainable development, taking into account the priorities established in the 2030 agenda.

We highlight the fact that the entities operating in the field of forestry exploitation, with an over-average turnover, are more concerned with the acceleration of the rotational speed of the circulating assets with direct favorable effects on the performance indicators (benefit and rate of return). They have negative effects on the decrease of the forest fund through its administration policies, which may conflict with article No. 14 of the European Union 2030 Agenda.

In order to meet the conditions of profitability and sustainability, the community forestry enterprises must have: transparent commercial forest rights, strong social organization and competitive business skills.

We believe that based on the results that are conjoined with those of Pohoata's study [50], both forest service operators and responsible entities could implement a sustainable forest-specific development model, especially when all these operators enjoy a relatively low-performing and cost-effective activity.

Starting from the recommendations made in [51, 52], we can state that the results obtained may also be the foundation for a business model, that are specific to forestry entities, on the basis of which sustainable development strategies will be built in line with 2030 agenda requirements.

\section{Conclusions}

Over the last 40 years the forests have been depleted due to population increase, economic imperatives, charcoal production, demand for new land for agriculture and uncontrolled fires.

The analysis carried out in this study has allowed the evaluation of sustainable development procedures that forestry firms in the northeastern region apply to their strategic business development policies on profitability and patrimony accumulation channels. At the same time, the analysis assessed the risks and vulnerabilities related to sustainable development, differentiated on the three types of activities related to the NACE codes $(210,220$, 230-240), these risks and vulnerabilities in sustainable development identifying the potential of a group of 200 entities to meet the objectives set by the European fora through the 2030 Agenda on Sustainable Development.

The proposed model proved to be a homogeneous, statistically significant one for the studied phenomenon, statistical tests confirming the robustness of the model and its adaptable flexibility for several categories of activities in the sense of sustainable development.

Our study is the first attempt to address the relationship between determinants of sustainable performance and financial performance for forestry companies operating in the northeastern Romania. The main findings of this research might have important implications for management, because a strong connection between CSP and FP is an important driver of sustained competitive advantage. In other words, companies learn to run their businesses by assessing both their economic and social roles.

Coming back to final results, we can state that in order to verify the sustainability of forest operators in the operational activity, it is necessary to analyze the main performance indicators that underlie the development of specific instruments such as: the environmental budget, sustainable environmental/environmental performance assessment systems, environmental control, and the stability scorecard balance. In order to be able to implement these approaches, forestry entities should implement a sustainability control system that works in parallel with the management control system - even if the pressure exerted by the legislative and social factors could constitute barriers that are difficult to be eliminated.

In this context, we believe that it is important and necessary at the same time to integrate all the aspects related to sustainability within the management control system and the managerial results. They should not only be reflected by the value of the financial indicators presented in our research, but also obeying the principles and values which lead to sustainable development, such as: the need to find support solutions for social, environmental and economic sustainability in the management process by incorporating social and environmental issues into management strategies. Taking into account the fact that economic sustainability 
creates value through the production of goods and values, or the provision of high-quality services, these entities should be made to understand the process of creating value not only from a financial perspective but also in the report with the other categories of stakeholders, together with the importance of protecting natural resources, by observing environmental policies and avoiding actions that will harm them, basically by re-examining the issues related to social sustainability.

The implementation of sustainability policies in line with the requirements of the European Agenda 2030 at the level of the forestry entities basically implies, ensuring a balanced and efficient management of the interconnection relations between the entity, society and the state, as well as using the potential of these interactions to their fullest.

\section{Acknowledgements}

This work is supported by project POCU 125040, titled "Development of the tertiary university education to support the economic growth - PROGRESSIO," co-financed by the European Social Fund under the Human Capital Operational Program 2014-2020.

\section{Conflict of Interest}

The authors declare no conflict of interest.

\section{References}

1. BIOLLEY H.E. Cultural gardening. Journal Forestier Suisse, 52 (6), 97, 1901 [In French].

2. BAKER F.S. First Edition 1950 Principles of Silviculture F.S. Baker (First edition). McGraw-Hill, 1950.

3. DROLET S., LEBEL L. Forest harvesting entrepreneurs, perception of their business status and its influence on performance evaluation, Forest Policy and Economics 12 (4), 287, 2010, DOI: 10.1016/j.forpol.2009.11.004

4. BOSTAN I., GROSU V. Legislative and financial perspectives on the environmental policies of Romania. J. Food Agric. Environ, 11 (2), 918, 2013.

5. DRAGOI M., POPA B., BLUJDEA V. Improving communication among stakeholders through ex-post transactional analysis - case study on Romanian forestry. Forest Policy and Economics, 13 (1), 16, 2011.

6. National Rural Development Program 2007-2013 - version XI. (2013, November). Available online: http://www.madr. ro/docs/dezvoltare-rurala/PNDR_2007-2013_versiuneaconsolidata-nov2013.pdf (accessed on 12 December 2018).

7. IONESCU R.V., ZLATI M.L., ANTOHI V.M., STANCIU S. Reduced Inequalities as Factor of Sustainable Development: The Analysis Under Econometric Models. Sustainability, 10 (10), 3523, 2018.

8. MARINELLI A., CASINI L. Aspects of the turkey oak management in Italy. In Prospettive di valorizzazione delle cerrete dell'Italia Centro Meridionale, Regione Basilicata, 1989 [In Italian].
9. KUVAN Y., EROL S.Y., YILDIRIM H.T. Forest Managers' Perception of the Foremost Forestry Issues, Problems and Forest Functions in Turkey. Polish Journal of Environmental Studies 20 (2), 393, 2010.

10. COSMULESE C.G., MIHAI L. The importance of forestry at macroeconomic and microeconomic level, Ecoforum Journal, 8, 1 (18), 2019. Available online: http:// www.ecoforumjournal.ro/index.php/eco (accessed on 12 February 2019).

11. ZLATI M.L., ANTOHI V.M. Accounting treatments and policies for biological assets from the perspective of IAS 41-Agriculture. Risk in Contemporary Economy, 104, 2018.

12. ZLATI M.L., ANTOHI V.M. Analysis of Economic Efficiency through the Analytical Budgeting Method using Econometric Modelling. Annals of the University Dunarea de Jos of Galati: Fascicle: I, Economics \& Applied Informatics, 24 (1), 2018.

13. BOURIAUD L., MARZANO M. Conservation, extraction and corruption: Is sustainable forest management possible in Romania. In Natural resource extraction and indigenous livelihoods: Development challenges in an era of globalization, 221, 2016.

14. BUDIANSCHI D., GALUPA D., GU I., BACAL P., ERMURACHI V. Efficiency and Transparency of the Use of Forest Resources Resources, 2013. Available online: http://www.moldsilva.gov.md/public/files/1111/Eficienta si_transparenta_utilizarii_resurselor_fondului_forestier. pdf (accessed on 12 December 2018).

15. NICHIFOREL R., NICHIFOREL L. Perception of relevant stakeholders on the potential of the implementation of the" Due Diligence" system in combating illegal logging in Romania. Journal of Horticulture, Forestry and Biotechnology, 15 (3), 126, 2011.

16. DACKO M., DACKO A. Management of the Natural Environment - A Systemic Approach. Journal Polish of Enviromental Studies 18, 145, 2009.

17. Report on EU Action for Sustainability of June 2017. (2017, June). Available online: http://www.europarl.europa.eu/ sides/getdoc.do? pubref=-//ep//nonsgml+report+a8-20170239+0+doc $+\mathrm{pdf}+\mathrm{v} 0 / / \mathrm{en}$ (accessed on 13 December 2018).

18. PETTENELLAD. The new challenges for the forestry sector: market, energy, environment and policies. Roma: Tellus, 2009 [In Italy]

19. BRUN F., MOSSO A., BLANC S. Activity of forestry companies operating in the Piedmont region during 20112012. 2014. Available online: http://www.regione.piemonte. it/foreste/images/files/pubblicazioni/aifo.pdfv (accessed on 13 December 2018) [In Italian].

20. BOSTAN I., MATES D., GROSU V., SOCOLIUC M. Implications of fiscality over accounting in agriculture. Bulletin of the University of Agricultural Sciences \& Veterinary Medicine Cluj-Napoca. Horticulture, 65 (2), 432, 2008.

21. HASNAOUI A., KROTT M. Political Drivers of Forest Management in Mediterranean Countries: A Comparative Study of Tunisia, Italy, Portugal and Turkey. Journal of New Sciences, CIRS (14). 2017. Available online: http:// www.jnsciences.org/agri-biotech/77-volume-spcialconfrence-cirs-2017/484-political-drivers-of-forestmanagement-in-mediterranean-countries-a-comparativestudy-of-tunisia,-italy,-portugal-and-turkey.html, (accessed on 13 December 2018).

22. CHAUVIN C., RENAUD J.P., RUPÉ C., LECLERC D. Stability and management protective forests. ONF-Bulletin Technique, 27, 37, 1994 [In French]. 
23. PIUSSI P., FARRELL E.P. Interactions between society and forest ecosystems: challenges for the near future. Forest Ecology and Management, 132 (1), 21, 2000.

24. BEBI P., KIENAST F., SCHÖNENBERGER W. Assessing structures in mountain forests as a basis for investigating the forests' dynamics and protective function. Forest Ecology and Management, 145 (1-2), 3, 2001.

25. MOTTA R., EDOUARD J.L. Stand structure and dynamics in a mixed and multilayered forest in the Upper Susa Valley, Piedmont, Italy. Canadian Journal of Forest Research, 35 (1), 21, 2005.

26. MALESIOS C., SKOULOUDIS A., DEY P.K., ABDELAZIZ F.B., KANTARTZIS A., EVANGELINOS $\mathrm{K}$. Impact of small- and medium-sized enterprises sustainability practices and performance on economic growth from a managerial perspective: Modeling considerations and empirical analysis results. Business Strategy and the Environment, 27 (7), 960, 2018.

27. YOO W.-J., CHOO H., LEE S., A Study on the sustainable growth of SMEs: The mediating role of organizational metacognition. Sustainability 10, 2829, 2018.

28. CIUBOTARIU M.S. The role of small and medium enterprises in the modern economy and the importance of IFRS application for SMEs, The Annals of The „Stefan cel Mare University of Suceava, Fascicle of The Faculty of Economics and Public Administration, 13, 1 (17), 201, 2013.

29. WADDOCK S.A., GRAVES S.B. The corporate social performance-financial performance link. Strategic Management Journal, 18 (4), 303, 1997.

30. SURROCA J., TRIBÓ J.A., WADDOCK S. Corporate responsibility and financial performance: The role of intangible resources. Strategic Management Journal, 31 (5), 463, 2010.

31. PULLMAN M.E., MALONI M.J., CARTER C R. Food for thought: social versus environmental sustainability practices and performance outcomes. Journal of Supply Chain Management, 45 (4), 38, 2009.

32. WANG Z., SARKIS J. Corporate social responsibility governance, outcomes, and financial performance. Journal of Cleaner Production, 162, 1607, 2017.

33. VIRAG N.P., MATEȘ D., ARDELEAN D., FEIEȘ C.G. Environmental accounting: a management tool for sustainable development, Journal Studia Universitatis „Vasile Goldiş" Arad, Seria Ştiinţe Economice”, 24 (4), 164, 2014.

34. BURCA V., MATES D. Implications of IFRS adoption on earnings quality, empirical case for Romanian environment, Annales Universitatis Apulensis Series Oeconomica, [S.1.], 1 (17), 58, 2015.

35. LAARI S., TÖYLI J., OJALA L. The effect of a competitive strategy and green supply chain management on the financial and environmental performance of logistics service providers. Business Strategy and the Environment, 27 (7), 872, 2018.

36. BURCIU A. MBO \& Ciclul Afacerilor. Management by Objectives \& Business Cycle Economică, București, 1999 [In Romania].

37. FIGGE F., HAHN T. Sustainable Value Added - measuring corporate contributions to sustainability beyond ecoefficiency. Ecological Economics 48, 173, 2004. https://doi. org/10.1016/j.ecolecon.2003.08.005

38. LOURENÇO I.C., BRANCO M.C., CURTO J.D., EUGÉNIO T. How Does the Market Value Corporate
Sustainability Performance? Journal of Business Ethics 108, 417, 2012. https://doi.org/10.1007/s10551-011-1102-8

39. JUNG S., NAM C., YANG D.H., KIM S., Does Corporate Sustainability Performance Increase Corporate Financial Performance? Focusing on the Information and Communication Technology Industry in Korea: Corporate sustainability and financial performance. Sustainable Development 26, 243, 2018. https://doi.org/10.1002/sd.1698

40. BARNEY J. Firm Resources and Sustained Competitive Advantage. Journal of Management 99, 1991.

41. ARTIACH T., LEE D., NELSON D., WALKER J. The determinants of corporate sustainability performance. Accounting \& Finance 50, 31, 2010. https://doi.org/10.1111/ j.1467-629X.2009.00315,

42. REYES-MENENDEZ A., SAURA J., PALOS-SANCHEZ P., ALVAREZ-GARCIA J. Understanding User Behavioral Intention to Adopt a Search Engine that Promotes Sustainable Water Management. Symmetry, 10, 584, 2018.

43. MEADOWS D.H., MEADOWS D.L., RANDERS J., BEHRENS III, W.EW. The Limits to Growth. Universe Books, NY, 1972.

44. MEADOWS D.H., MEADOWS D.L., RANDERS J. Beyond the limits: confronting global collapse, envisioning a sustainable future. Chelsea Green Pub. Co, Post Mills, Vt., 1992.

45. CIEŚLAK I., PAWLEWICZ K., PAWLEWICZ A. Sustainable Development in Polish Regions: a Shift-Share Analysis. Polish Journal of Environmental Studies 28, 565, 2018. https://doi.org/10.15244/pjoes/85206

46. BÜYÜKÖZKAN G., KARABULUT Y. Sustainability performance evaluation: Literature review and future directions. Journal of Environmental Management 217, 253, 2018. https://doi.org/10.1016/j.jenvman.2018.03.064

47. MARSHALL J.D., TOFFEL M.W. Framing the Elusive Concept of Sustainability: A Sustainability Hierarchy. Environmental Science \& Technology 39, 673, 2005. https://doi.org/10.1021/es040394k

48. HANAAES K., BALU B., DAVID A., MING T.K., VELKEN I., KRUSCHWITZ N., HOPKINS M.S. First Look: The Second Annual Sustainability \& Innovation Survey. The Boston Consulting Group, 2011.

49. HUSSAIN N., RIGONI U., ORIJ R.P. Corporate governance and sustainability performance: Analysis of triple bottom line performance. Journal of Business Ethics, 149 (2), 411, 2018.

50. POHOAȚĂ I., Economic philosophy and the policy of sustainable development. Economică, București, 2003 [In Romanian].

51. HAJDÚCHOVÁ I., GIERTLIOVA B., SULEK R. Specifics of forest enterprises' performance measurement. Austrian Journal of Forest Science, 1, 23, 2017.

52. MACQUEEN D. Building profitable and sustainable community forest enterprises: enabling conditions. International Institute for Environment and Development (IIED), 2010, Available online: http://citeseerx.ist.psu.edu/ viewdoc/download?doi=10.1.1.453.6091\&rep=rep1\&type $=$ pdf

53. SPANGENBERG J.H., BONNIOT O. Sustainability indicators: a compass on the road towards sustainability. Wuppertal papers, 1998.

54. WANG Y.-S., CHEN Y.-J. Corporate social responsibility and financial performance: Event study cases. Journal of Economic Interaction and Coordination, 12 (2), 193, 2015. 
55. WANG Z., SARKIS J. Investigating the relationship of sustainable supply chain management with corporate financial performance. International Journal of Productivity and Performance Management, 62 (8), 871, 2013.

56. BERNARD Y., GODARD L., ZOUAOUI M. The Effect of CEOs' Turnover on the Corporate Sustainability Performance of French Firms. Journal of Business Ethics, 150 (4), 1049, 2018.

57. XIAO C., WANG Q., VAN DER VAART T., VAN DONK D.P. When does corporate sustainability performance pay off? The impact of country-level sustainability performance. Ecological Economics, 146, 325, 2018.

58. PROGRAMME of the Romanian Presidency of the Council of the European Union 1 January - 30 June 2019, Available online: https://www.romania2019.eu/wpcontent/uploads/2017/11/en_rogramme_ropres2019.pdf (accessed on 05 July 2019).

59. www.topfirme.com

60. ORLITZKY M., SCHMIDT F.L., RYNES S.L. Corporate social and financial performance: A meta-analysis. Organization Studies, 24 (3), 403, 2003. 
